\title{
Investigating the tectonic influence to the anthropogenic subsidence along northern coast of Java Island Indonesia using GNSS data sets
}

\author{
Heri Andreas ${ }^{1, *}$, Hasanuddin Zainal Abidin ${ }^{1}$, Dina Anggreni Sarsito ${ }^{1}$, Irwan Meilano $^{1}$ and Susilo ${ }^{2}$ \\ ${ }^{1}$ Geodesy Research Division, Faculty of Earth Science and Technology, Institute of Technology Bandung, Indonesia \\ ${ }^{2}$ Indonesia Geospatial Agency (Badan Informasi Geospasial), Indonesia
}

\begin{abstract}
Geodetic measurements (e.g. Spirit Leveling, GNSS and InSAR) have clearly measured the land subsidence in many parts along northern coast of Java Island Indonesia. The impacts from the subsidence (e.g. problems on infrastructures, wider expansion of flooding, tidal inundation, etc.) are significantly appeared in certain places and already concluded as ecological disaster. Since mostly the land subsidence are located in cities lying on sediment area like Jakarta, Pekalongan, Semarang, Demak, and Surabaya where consumption of groundwater is very huge, in this case the typical of subsidence might be categorize as anthropogenic land subsidence. Nevertheless in order to make sure this typical, in this case the investigation on the others factors like the tectonic influence is necessary (e.g. as key for appropriate of adaptation or mitigation from disaster).This paper will highlight the investigation by using GNSS dataset in order to see the tectonic influence to the anthropogenic subsidence along northern coast of Java Island. Our preliminary result shows relatively lack of tectonic influence to the anthropogenic subsidence around the investigated area.
\end{abstract}

\section{Introduction}

Northern coast of Java lies along the Island of Java, the Island which is recorded as densest population in Indonesia. The straight length of the coastal is approximately reached 1000 kilometer. This area is one of the strategic places for our National development. Many of urban area including big cities like Jakarta, Bekasi, Cirebon, Tegal, Pekalongan, Semarang, and Surabaya lies along this area. More than $50 \%$ of people in Java Island living in the cities including the coastal city as mentioned here. Within the urban areas especially along the northern coast of Java, many of industrial area and trading area are being established. Others shape like farm land, fishpond, etc. lies also along the area. Many facilities can be found along the area such as big harbor (e.g. Tanjung Priok in Jakarta, Tanjung Mas in Semarang and Tanjung Perak in Surabaya). Toll road is also establishing along northern of Java Island. The toll road projected to connect the most western part of the Island (Merak) to the most eastern part (Banyuwangi). Until today the toll road segment from Merak to Surabaya is about to finished. This toll road is also belonging to the ASEAN highway. Within these infrastructures, the future development of urban area including the facilities in northern coast of Java will be very huge.

In spite of remarkable development, many places around northern coast of Java island are experiencing land subsidence with the rates vary from few centimeter to order of tens centimeter per year. According to some publications (e.g. Murdohardono and Tirtomihardjo [1], Murdohardono and Sudarsono [2], Rajiyowiryono [3], Abidin et. al [4-8], Koudogbo et. al [9], Ng, A.H.-M et.al [10], Chaussard et. al [11]) the yearly value of Jakarta's subsidence generally ranging from 1 to 10 centimeter per-year and may reach 20-26 centimeter in certain place, especially in northern part of Jakarta city for the recent years. Meanwhile, land subsidence in Bekasi is around 1-10 centimeter per year with large subsidence are happening in district of Cikarang and Downtown of Bekasi (Chaussard et. al [11]). Still according to Chaussard et. al [11] land subsidence around Pondok Bali area, Pamanukan area and pekalongan area are varying between 2 to 10 centimeters per year for recent years. Further to the east we can see Land subsidence in Semarang and Demak ranging from 1 to 17 centimeter per-year (Marfai et. al [12], Murdohardono et. al [13], Kuehn et. al [14], Lubis et al [15], Chaussard.et. al [11], Andreas et al. [16]). Surabaya area are experiencing large subsidence with rate of about 1-5 centimeter per year. It is probably many other places in the northern coast of Java island are experiencing land subsidence but still unmeasured. Figure 1 shows map of land subsidence in Jakarta, Bekasi, Pondok Bali Blanakan, Pamanukan, Pekalongan, Semarang and Demak. As we can see geodetic measurements (e.g. Spirit Leveling, GNSS and InSAR) have clearly measured the land subsidence in the areas.

\footnotetext{
*Corresponding author: heriandreas49@gmail.com
} 


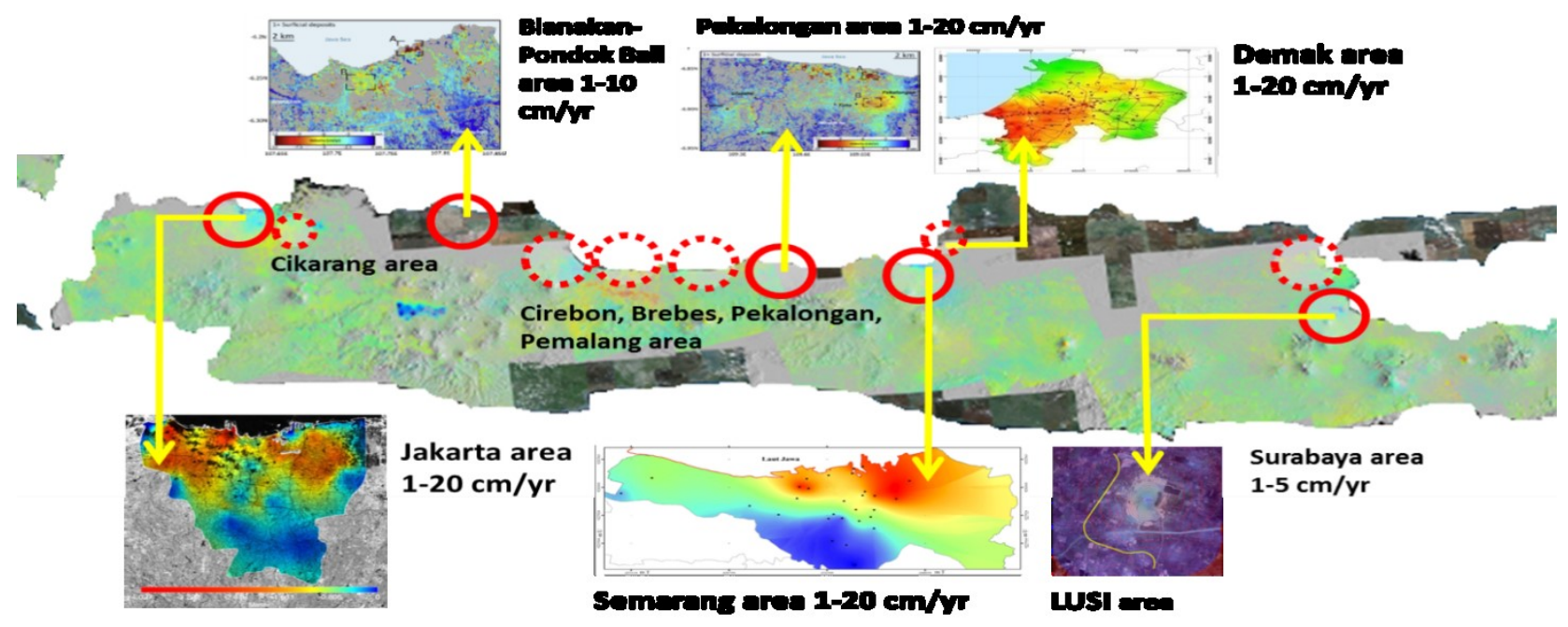

Fig. 1. Map shows many places around Java island are experiencing land subsidence (e.g. Jakarta, Pekalongan, Semarang, Demak, etc.) with the rates vary from few centimeter to order of tens to twenty centimeter per year.

The impact of land subsidence in Java Island especially around northern coast of the island can be seen in several forms, such as the wider expansion of (coastal) flooding areas, cracking of buildings and infrastructure, and increased inland sea water intrusion (Sutanta et. al [17], Mazzoti et. al [18], Andreas et. al [19-20]. It also badly influences the quality and amenity of the living environment and life (e.g. health and sanitation condition) in the affected areas. Some people indeed have been evacuated from their origin place. The place now become sea. The economic losses caused by land subsidence in Java Island are enormous; since many buildings and infrastructure severely affected and its collateral coastal flooding disasters in many places are located in the industrial zone, housing, farming, fish pond, etc. Off course a large number of populations are also exposed to this silent disaster. The corresponding maintenance cost is increasing every year. The living conditions of the affected population are deteriorating. The quality of social and economic activity is consequently decreasing as well. So, adaptation and mitigation are considered very important especially along northern coast of the Island. Sometime in the future if less action taken in adaptation and mitigation, ecological disaster would be more and more significant. Figure 2 shows the impacts of land subsidence along northern coast of Java Island which are already recognize among others which are probably believed still quietly unrevealed but it is there.

Question arises in regard to adaptation and mitigation is what would be the causes of the subsidence in the area. The tectonic is one of the suspected causes along with anthropogenic causes (e.g. ground water overexploitation). The question is very important for proper and effective mitigation or adaptation. As we can see the impact like damaging on infrastructures, wider area expansion of flood, etc. indeed they are formed a quite serious disaster now. If the tectonic play significant role, in this case the adaptation is more effective than mitigation. If the tectonic indeed is lack influencing, in this case we should focus to another causes and do better appropriate mitigation and or adaptation.
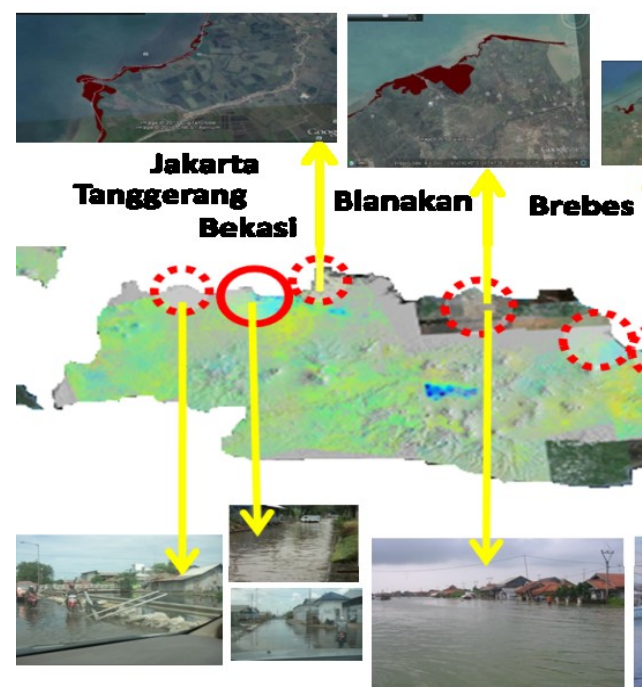

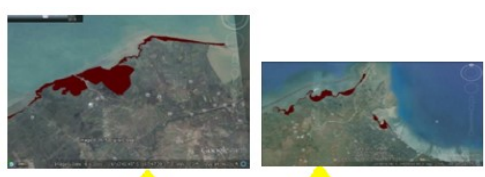

Pekalongan Pemalang
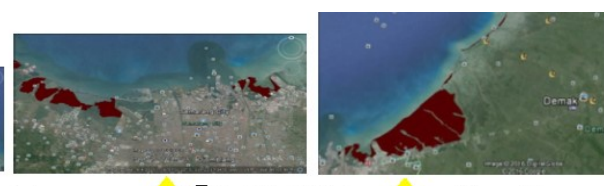

Gresik Surabaya Demak
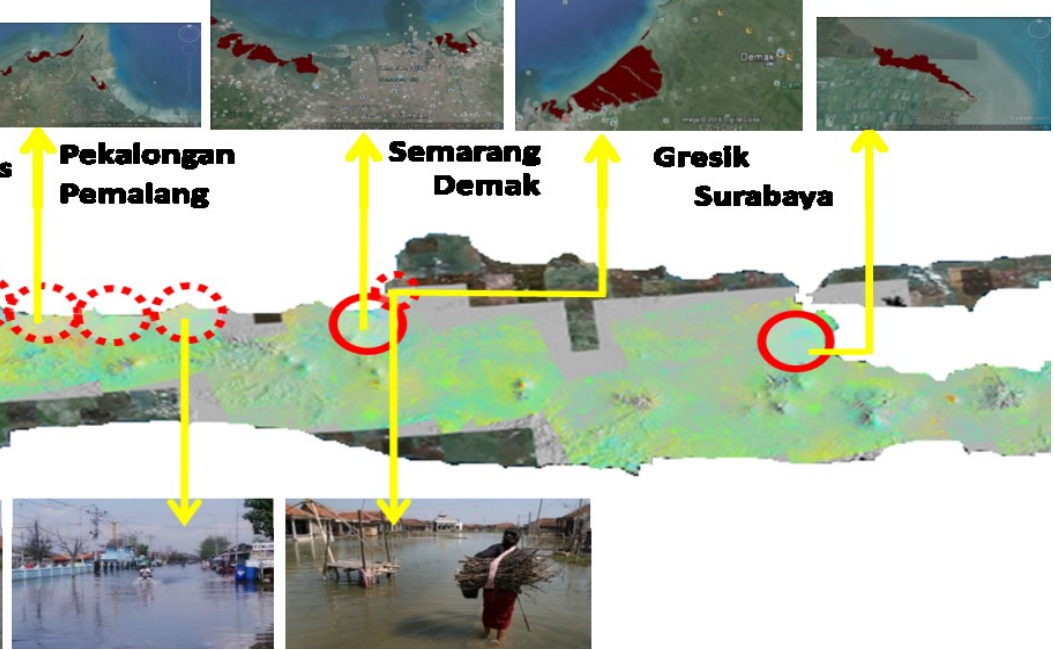

Fig.2. The impact of land subsidence in form of tidal inundation along northern coast of Java Island (e.g. Jakarta, Semarang, etc.) 


\section{Method}

When the plates meet each other there are mechanisms where one plate can subduct the other plate. The oceanic plate which has more weight is subducting the continental plate which has lighter weight. On the subduction zone there will part which are locked each other due to a friction and we call it seismogenic zone. As an oceanic plate is continuing to move and given a force, in this case the continental plate is experiencing deformation. As the consequences the fore arc basins is usually experiencing both uplift and submerge (subsidence) in certain part. The submerge mechanism we also call it tectonic subsidence. After sometime when the seismogenic zone reaches the maximum stress on the locked, latter on the locked can break and produce the earthquake (Hudnut [21], Bock et. al [22]). This moment we call it coseismic phase followed by postseismic. At these phases, the fore arc basin usually experiencing both uplift and subsidence in reverse.
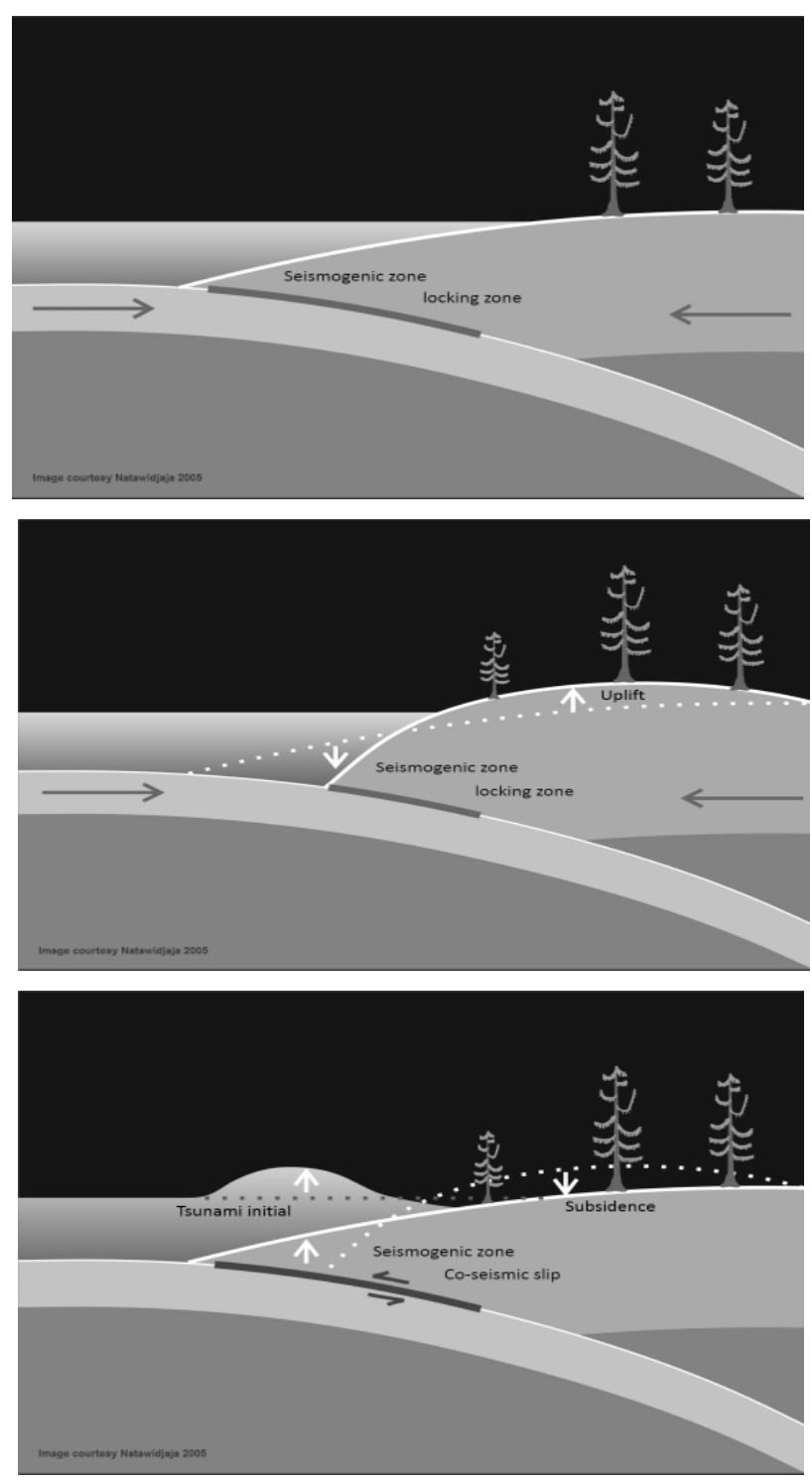

Fig.3.Illustration of uplift and submerge (subsidence) in the subduction zone.
Since basically the tectonic subsidence is a temporal variation on position at vertical component (e.g. Height), in this case measurement technology like GNSS GPS is one of the best tools to choose. We in this case choose GNSS GPS campaign and continuous for investigating the tectonic subsidence around northern coast of Java Island. The campaign mode means we regularly (e.g. monthly or yearly basis) measured the GPS satellites for about 12 to 48 hours, meanwhile continuous mode means we observe GPS satellite 24 hour a day and 7 in a week continuously. In this investigation luckily we have CORS network belong to BIG, our national geospatial agency that can be analyzed. At Java Island there are around 40 CORS station that can be used to analyze the tectonic subsidence of Java Island. Figure 4 shown illustrations of GNSS GPS surveys on investigating tectonic subsidence.

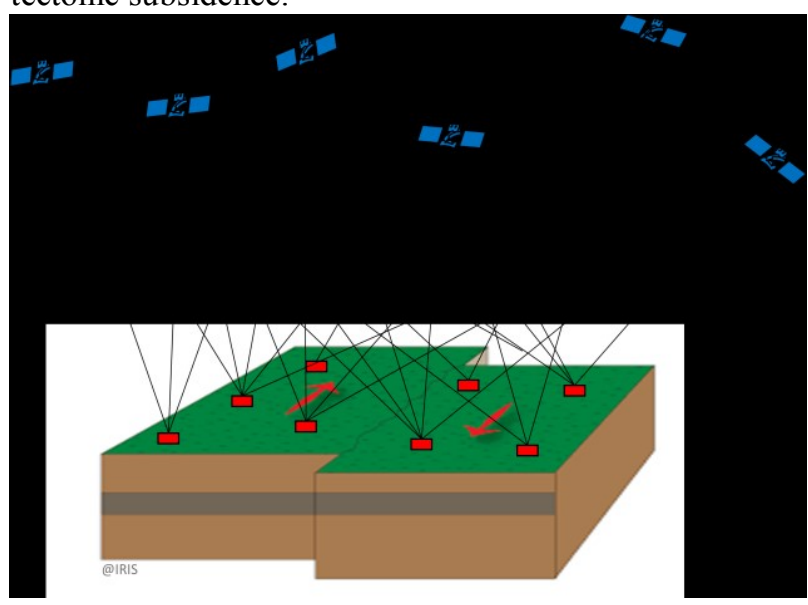

Fig.4. Method on investigating tectonic subsidence by using GNSS GPS. Monitoring point located in tectonic active area and it position especially the vertical components is investigation in time series.

Figure 5 shows documentation of Benchmark of CORS BIG in the field and also map of all Benchmark around Java Island. The Benchmark installed deeply on the ground for about one and a half meter. There are also Benchmark with steel pile attached to the ground below until 5-6 meter. The location arrange so they can see the movement of the plate. It mean it is very stable area, save from local movement like landslide or else.

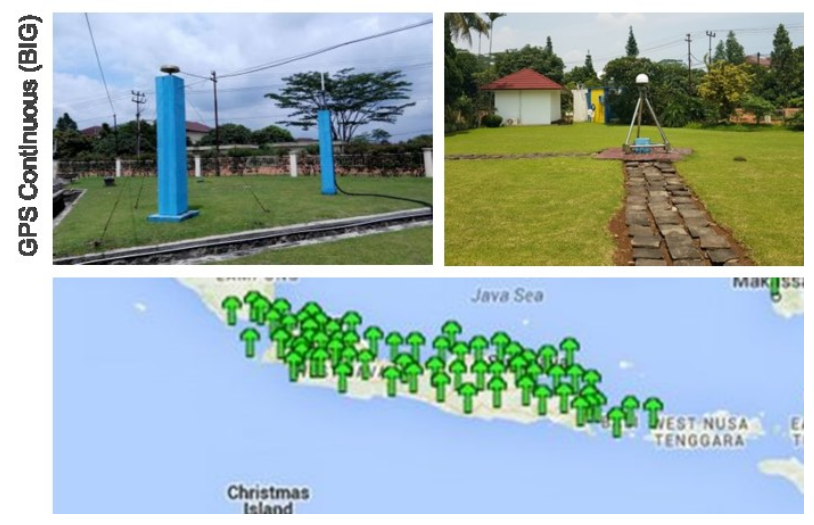

Fig.5. Documentation of Benchmark of CORS BIG and map of all location of Benchmark around Java Island. 
Simply by comparing each height component position in a function of times (e.g time series), we can see whether the tectonic subsidence is there or generally not existed over northern coast of Java Island. For example if we found rate of 0.00 meters per year on the height component position changing, in this case no tectonic subsidence is existed. According to some publications, linier trend with very small magnitude (millimeter up to few centimeters per year) if existed may represent interseismic load from tectonic event (Hudnut [21], Bock et. al [22])

All of GNSS GPS data campaign and continuous taken for investigation tectonic subsidence on Java island were processed using scientific GPS software (e.g. Gamit Software) and completed with other scientific software as well (e.g. Bernese). This scientific software is commonly used for achieving the good accuracy level of relative coordinates from GPS surveyed data. All of errors and biases (e.g. Ionosphere, troposphere biases, cycle slip, phase ambiguity, antenna phase center bias, etc.) will be estimated or modeled and leaving the residual mostly only in few millimeter. Since the baseline from each combination of data will exceed typical of short baseline, in this case good handling of parameters errors and biases are crucial for high accuracy requirements especialy for vertical component. Table 1 and 2 each shows parameters of observation strategy and processing strategy.

Table 1. Parameters of observation strategy in order to monitor tectonic subsidence by using GPS technology.

\begin{tabular}{|l|l|}
\hline \multicolumn{2}{|c|}{ Paremeters observation strategy } \\
\hline Receiver & Geodetic Type dual frequency \\
\hline Observation rate & 30 seconds \\
\hline Observation length & $\begin{array}{l}\text { Continuously for CORS } \\
\text { station and 48 hour for } \\
\text { campaign measurements }\end{array}$ \\
\hline Mask Angle & 15 degree \\
\hline Data collected & Code and Phase \\
\hline Others data & $\begin{array}{l}\text { Field condition, obstruction, } \\
\text { etc. }\end{array}$ \\
\hline
\end{tabular}

Table 2. Parameters of processing strategy in order to monitor tectonic subsidence by using GPS technology

\begin{tabular}{|l|l|}
\hline \multicolumn{2}{|c|}{ Parameters processing strategy } \\
\hline Orbit and references & $\begin{array}{l}\text { Precise ephemeris, Earth } \\
\text { Rotation Parameters }\end{array}$ \\
\hline Atmospheric biases & $\begin{array}{l}\text { Combination of dual } \\
\text { frequency for ionosphere and } \\
\text { estimation for troposphere }\end{array}$ \\
\hline Antenna & Phase center correction \\
\hline Phase ambiguity & QIF strategy \\
\hline $\begin{array}{l}\text { Other biases and } \\
\text { errors }\end{array}$ & Differencing and neglected \\
\hline
\end{tabular}

From comparing each height in a function of time is simply enough to see the tectonic subsidence if existed or not in that particular point. Nevertheless if we would like to see spatially for whole the Island on how is the tectonic subsidence characteristic looks alike then we need to do modeling. On this investigation we work with two models to explain about tectonic subsidence model on Java Island. The first model is simply the gridding model while the second one using mechanism of subduction process by elastic half space model (Okada model) (Okada et. al [23]).

Gridding is just simply geometric approach of interpolation. From all the GNSS GPS results we create grid sample and then followed by interpolation. We can use Krigging method for the interpolation or else. As a result of interpolation we visualize on map showing spatial distribution of any value of deformation.

Mechanism of subduction represent by elastic half space in general explanation is estimation of slip by forces on fault plane on subduction zone in three components U1 (slip sliding to each plate), U2 (slip perpendicular to the plate), U3 (opening) generate deformation on the surface. Figure 6 shows the illustration on slip by forces. On the figure we can see also dip angle of plate $(\delta)$, length of fault plane (L) wide of fault plane (W) and depth of fault centroid (d).

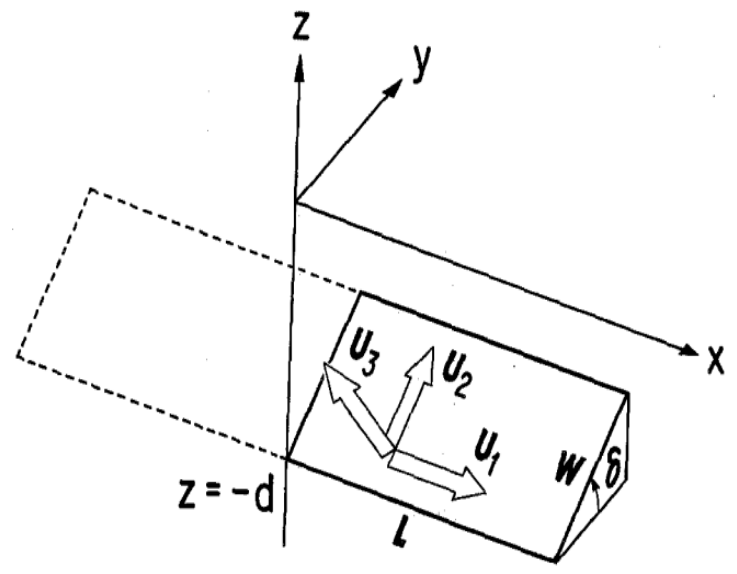

Fig.6. Mechanism of subduction represent by elastic half space. Basically explain the slip by forces on the fault plane.

Below we can see the equation 1 explaining mathematical processes on how slip by forces on fault plane on subduction zone in three components (uj) generate deformation on the surface (ui). We use strain as input parameters $(\xi)$. As for the physical properties we input lame constant $\alpha$ and $\mu$.

$u_{i}=\frac{1}{F} \iint_{z} \Delta u_{j}\left[\lambda \delta_{j k} \frac{\partial u_{i}^{n}}{\partial \xi_{n}}+\mu\left(\frac{\partial u_{i}^{j}}{\partial \xi_{k}}+\frac{\partial u_{i}^{k}}{\partial \xi_{j}}\right)\right] v_{k} d \Sigma$

On the process we do forward modeling calculation and we set up the fault plane base on historical mechanism of earthquake on the subduction zone in the southern of Java Island. We will first recognize segments of fault plane along west to east Java subduction zone. 


\section{Results}

After data processing we have more than thousands of height component coordinates solutions in each CORS BIG around Java Island (west, central and east), and plots each as time series. Data time span generally from 2011 until 2017 (five years). Meanwhile from around ten years of GPS campaign data, we also get the information of time series of height component coordinates solutions. Result of GPS data processing; especially for the vertical component shows the accuracy mostly in several millimeters to maximum only reach 1 centimeter. These results proved the software is capable on reducing significantly the biases and errors on GPS data. Generally only the residual of troposphere effect and the noise on the signal, those are still remains. With these accuracies we can confidently see the signal of deformation (e.g. tectonic subsidence) even in small value (e.g. only several millimeters per year).
Figure 7,8 and 9 each shows time series of example processed data CORS BIG namely CSIT which is located in Situbondo east Java, CLUM located in Lumajang area East Java, and CMAG located in Magetan east Java for years 2011 to 2017. All of the graphs in those 3 stations shows relatively flat trend, with accuracy of few millimeter after removing some noise and outlier. These three locations are located on stable area with Benchmark design and construction established to hopefully represent plate motions explained before. So if there are signal of deformation on the station in height component (e.g. we have indication of gradient time series) it would represent uplift or tectonic subsidence. Turn out for all of the graphs including the rest which they are not showed here informed relatively flat trend or nearly zero gradients. As a conclusion, the flat trend on the graphs represents almost zero tectonic subsidence. Neverteles modeling is created to make sure the conclusion.

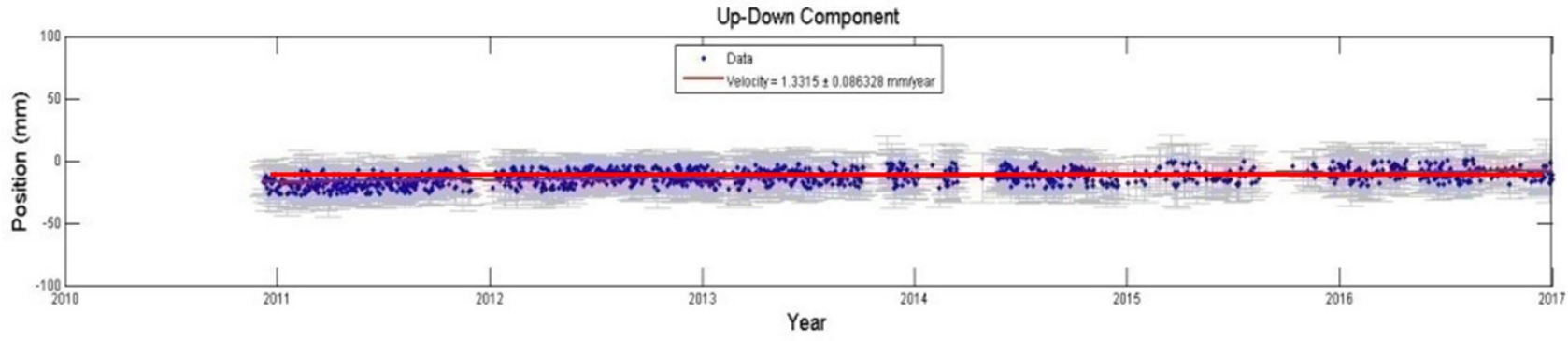

Fig.7. Ploted time series of vertical component/position of CORS BIG Station CSIT SitubondoEast Java from 2011 until 2017.

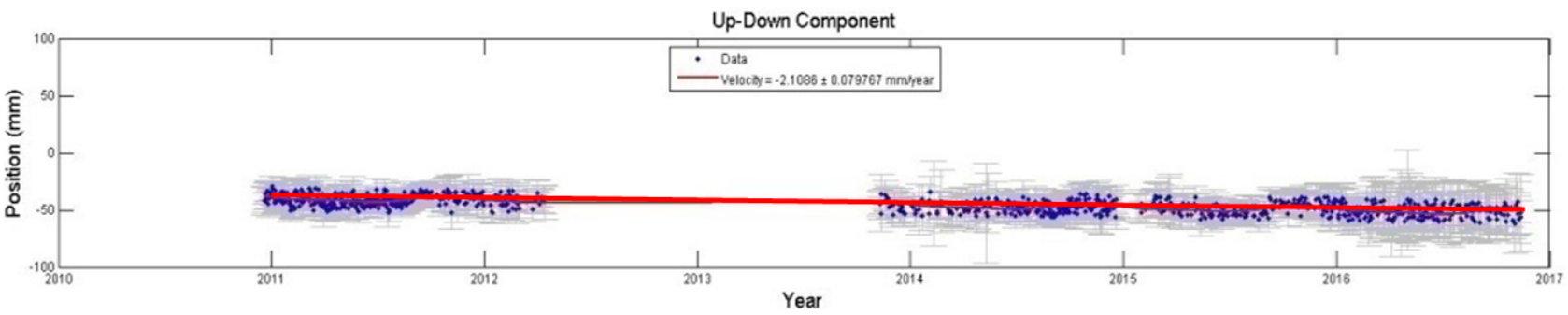

Fig.8. Ploted time series of vertical component/position of CORS BIG Station CLUMLumajangEast Java from 2011 until 2017.

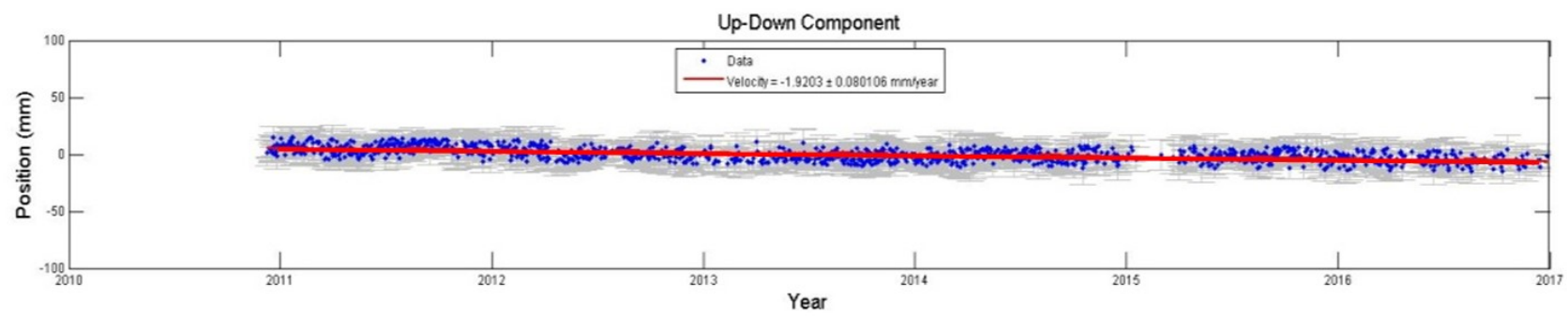

Fig.9. Ploted time series of vertical component/position of CORS BIG Station CMAG MagetanEast Java from 2011 until 2017.

As said on the method, we work with two models to explain about tectonic subsidence model on Java Island. The first model is simply the gridding model. Gridding is just simply geometric approach of interpolation. From all the GNSS GPS set results (rate per year on each height component) we create grid sample and then followed by interpolation. We use krigging method for the interpolation. More than 40 GNSS GPS points were included in the interpolation processes. As a result of interpolation we visualize on map showing spatial distribution of any value of deformation or zero value all over Java Island in a color range (figure 10). Blue indicate uplift, light yellow to bright orange indicate zero tectonic subsidence while dark orange indicate few millimeter of tectonic subsidence. For most of the Island seem zero tectonic subsidence are existed. Meanwhile there are few spot of tectonic subsidence even the values are relatively very small as we can say it belonging to zero tectonic subsidence as well. It is quite interesting to see on the map that there are several areas which are 
experiencing uplift (e.g. Southern part of west Java Island around Pelabuhan Ratu to the west until Ujung Kulon. If we talking forces from the subduction zone, it mean this areas have more energy accumulate compare to the other areas. As consequences this areas has more risk of earthquake disaster in the future.

As for the Jakarta area it is around 0.1-0.3 centimeter per year of negative value, for Blanakan area it is around 0.1-0.3 centimeter per year of negative value, for Pekalongan area it is around 0.1-0.3 centimeter per year of negative value, for Semarang and Demak it is around 0.1-0.5 centimeter per year of negative value, for Surabaya area it is around 0.0-0.01 centimeter per year of negative value. Generally almost no tectonic subsidence is taking places in all those areas.

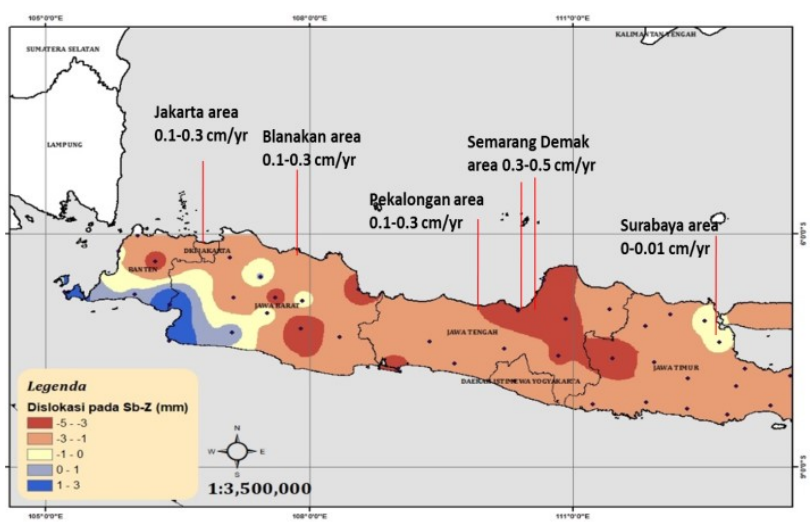

Fig.10. Map of tectonic subsidence and uplift on Java Island base on GNSS GPS data set gridding and interpolation.

The second model for investigation is elastic half space model Okada modeling. As mentioned on the method, we can see surface deformation from slip by the forces on the fault plane beneath the subduction zone. So we need to create the fault plane definition. We have choose four consequence of fault plane from west to east of java subduction zone (figure 11). This segmentation is based on historical evident, slab definition (Hanifa et.al [24], Hayes et. al [25]), etc. We recognize un-break segment below southern part of west Java and southern part of central Java while released segment was around Pangandaran area in 2006 and South of Banyuwangi area in 1994.

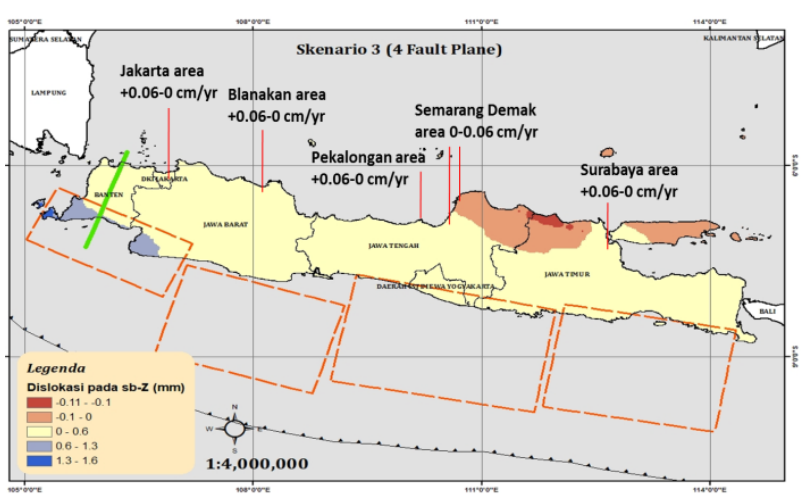

Fig.11. Map of tectonic subsidence and uplift on Java Island base on elastic half space model and GNSS GPS data set as input parameter.
Any value of deformation or zero value all over Java Island base on the Okada model is shown in a color range map (figure 11). Blue indicate uplift, light yellow to bright orange indicate zero tectonic subsidence while dark orange indicate few millimeter of tectonic subsidence. For most of the Island seem zero tectonic subsidence are existed. Meanwhile there are few spot of tectonic subsidence even the values are relatively very small and we can say it belonging to zero tectonic subsidence as well. It is quite interesting to see on the map that there are several areas which are experiencing uplift (e.g. southern part of west Java Island around Pelabuhan Ratu to the west until Ujung Kulon. We draw the cross section and make it on graph to show the uplift pattern (figure 12).

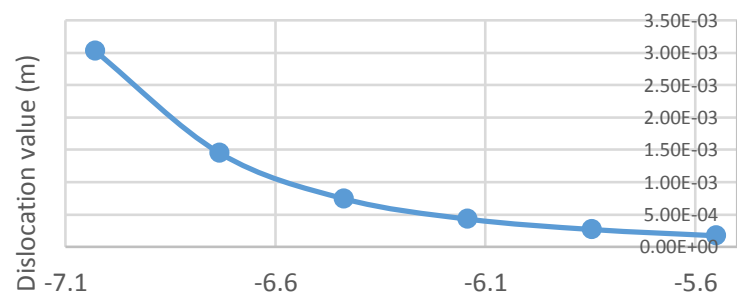

Latitude $\left({ }^{\circ}\right)$

Fig.12. Graph of cross section around southern part of west of Java showing the uplift pattern.

As for the Jakarta area, Blanakan, Pekalongan, Semarang, Demak dan Surabaya it is around 0 centimeter per year of value. Generally almost no tectonic subsidence is taking places in all those areas. So base on two model and trend on the graphs on each CORS BIG station we may concluded the lack of tectonic subsidence influence the anthropogenic land subsidence along the northern coast of Java Island Indonesia.

Table 3 shows parameters that are used in elastic half space Okada modeling Java subduction including dip angle of plate $(\delta)$, length of fault plane (L) wide of fault plane (W) and depth of fault centroid (d).

Table 3. Parameters that are used in elastic half space Okada modeling Java subduction.

\begin{tabular}{|c|c|c|c|c|}
\hline Parameter & Fault 1 & Fault 2 & Fault 3 & Fault 4 \\
\hline $\begin{array}{c}\text { Depth } \\
(\mathrm{km})\end{array}$ & $15-76$ & $16-135$ & $14-124$ & $14-124$ \\
\hline Dip $\left(^{0}\right)$ & $8-38$ & $8-47$ & $8-48$ & $9-48$ \\
\hline Strike & $239-315$ & $256-298$ & $265-294$ & $265-294$ \\
\hline $\begin{array}{c}\text { Length } \\
(\mathrm{km})\end{array}$ & 380 & 400 & 300 & 300 \\
\hline $\begin{array}{c}\text { Width } \\
(\mathrm{km})\end{array}$ & 200 & 260 & 260 & 260 \\
\hline Rake & -90 & -80 & -80 & -80 \\
\hline $\begin{array}{c}\text { Slip } \\
(\mathrm{cm} / \text { year })\end{array}$ & 6.7 & 6.7 & 6.7 & 6.7 \\
\hline $\begin{array}{c}\text { Open } \\
\text { Open }\end{array}$ & 0 & 0 & 0 & 0 \\
\hline
\end{tabular}




\section{Discussions}

Tectonic subsidence in Jakarta area, Blanakan, Pekalongan, Semarang, Demak and Surabaya is around 0 centimeter more less per year of value. Generally almost no tectonic subsidence is taking places in all those areas. Meanwhile antropogenic subsidence in Jakarta is around 1-20 centimeter per year, in Blanakan is around 1-10 centimeter per year, in Pekalongan is around 1-20 centimeter per year, Semarang and Demak is around 120 centimeter per year and in Surabaya is around 1-5 centimeter per year. We may concluded the lack of tectonic subsidence influence the anthropogenic land subsidence along the northern coast of Java Island
Indonesia. If we calculate how many percent of contribution, the natural (e.g. tectonic subsidence) contribute less than $3 \%$ of total subsidence magnitude while anthropogenic subsidence contributes $80-90 \%$.

So in order to choose appropriate mitigation and or adaptation we should pay more attention to the anthropogenic cause. We strongly believed that the exploitation of ground water is the main causes (Holjer and Thomas [26], Rajiyowiryono [3], Abidin et. al [27], JICA [28]). So, mitigation and or adaptation shoul start here. Many empirical example (Holjer and Thomas [26], JICA [28]), has prove that management of water (including groundwater) is best program of mitigation and or adaptation againts land subsidence.

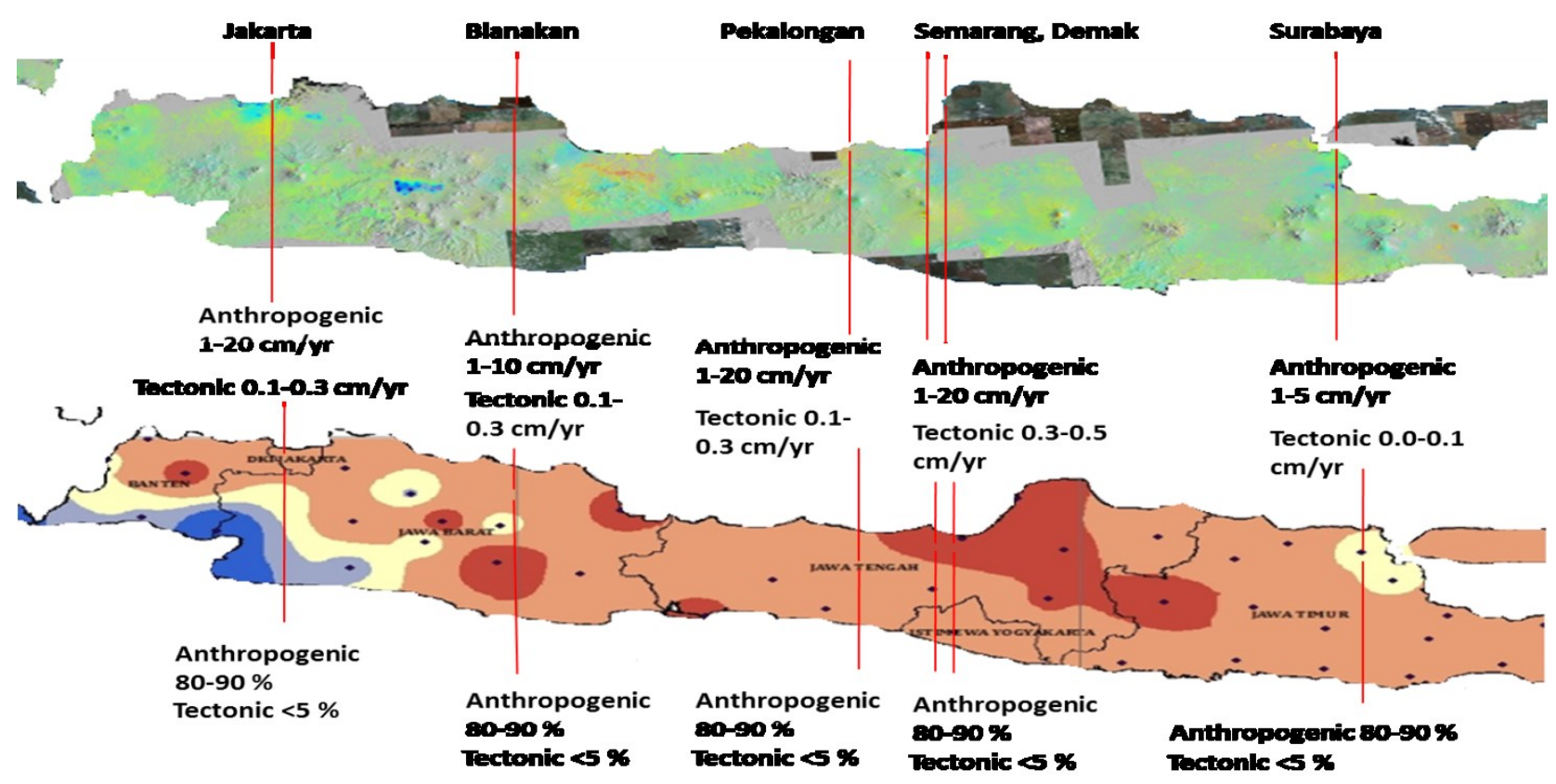

Fig.13. Comparation of land subsidence due to natural processes (e.g. tectonic, natural compaction) and due to antropogenic causes. For Jakarta and other urban places along northern coas of Java, the tectonic subsidence and natural compaction contribute less than $3 \%$ of total subsidence magnitude while anthropogenic subsidence contributes $80-90 \%$.

\section{Conclusion}

In spite of remarkable development, many places around northern coast of Java island is experiencing land subsidence with the rates vary from few centimeter to order of tens to twenty centimeter per year. The impact of land subsidence in this area can be seen in several forms, such as the wider expansion of (coastal) flooding areas, cracking of buildings and infrastructure, and increased inland sea water intrusion. It also badly influences the quality and amenity of the living environment and life (e.g. health and sanitation condition) in the affected areas. Some people indeed have been evacuated from their origin place. The place now become sea. The economic losses caused by land subsidence are enormous

So, adaptation and mitigation are considered very important. Sometime in the future if less action is taken in adaptation and mitigation, ecological disaster would be more and more significant. As a key of adaptation and mitigation we should start from understanding the main causes. If we found it then we can kill it. That is the simple phrase. Some people said tectonic is the main causes while the other said groundwater exploitation is the main (anthropogenic causes).

Base on investigation by using GNSS GPS data set, gridding technique and elastic half space modeling we found the tectonic subsidence (and natural compaction) contribute less than $3 \%$ of total subsidence magnitude while anthropogenic subsidence contribute $80-90 \%$. Tectonic subsidence in Jakarta area, Blanakan, Pekalongan, Semarang, Demak and Surabaya is around 0 centimeter more less per year of value while antropogenic subsidence in those areas is around 1-20 centimeter per year. Short story in order to choose appropriate mitigation and or adaptation we should pay more attention to the anthropogenic causes. We strongly believed that the exploitation of ground water is the main causes. We can neglect the tectonic causes. In Tokyo, Osaka, Shanghai, Bangkok, etc. when they stop taking the groudwater the subsidence is stopping. 


\section{Acknowledgements}

Many thanks and appreciation to students from ITB, from Dipenogoro University and the surveyors who helped the investigation in the field, and especially to the local people along northern coast of Java Island for kindly sharing the information and experience relating subsidence impacts.

\section{References}

1. Murdohardono, D dan Tirtomihardjo, H., Penurunan tananh di Jakarta dan rencana pemantauannya, In: Proceedings of the 22nd annual convention of the indonesian association of geologists, Bandung, 6-9 December, pp 346-354 (1993)

2. Murdohardono, D and Sudarsono, U., Land subsidence monitoring system in Jakarta, In: Proceedings of symposium on Japan-Indonesia IDNDR Project: Volcanology, tectonics, flood and sediment hazards, Bandung, 21-23 September, pp 243-256 (1998)

3. Rajiyowiryono, H. Groundwater and Land subsidence Monitoring along the North Coastal Plain of Java Island (CCOP Newsl 24(3):19 JulySeptember 1999)

4. Abidin, H. Z., R. Djaja, D. Darmawan, S. Hadi, A. Akbar, H. Rajiyowiryono, Y. Sudibyo, I. Meilano, M. A. Kusuma, J. Kahar, C. Subarya, Land Subsidence of Jakarta (Indonesia) and its GeodeticBased Monitoring System, Natural Hazards. Journal of the International Society of the Prevention and Mitigation of Natural Hazards, Vol. 23, No. 2/3, March, pp. 365 - 387 (2001)

5. Abidin, H.Z., R. Djaja, H. Andreas, M. Gamal, K. Hirose, Y. Maruyama, Capabilities and Constraints of Geodetic Techniques for Monitoring Land Subsidence in the Urban Areas of Indonesia, Geomatics Research Australia. No.81, December, pp. $45-58$ (2004)

6. Abidin, H.Z., Suitability of levelling, GPS and INSAR for monitoring land subsidence in urban areas of Indonesia, GIM Int 19(7):12-15 (2005)

7. Abidin, H.Z., H. Andreas, R. Djaja, D. Darmawan and M. Gamal, Land subsidence characteristics of Jakarta between 1997 and 2005, as estimated using GPS surveys, GPS Solutions, Springer Berlin / Heidelberg, Vol. 12, No. 1, pp. 23-32 (2008)

8. Abidin, H.Z., H. Andreas, I. Gumilar, Y. Fukuda, Y.E. Pohan, T. Deguchi, Land subsidence of Jakarta (Indonesia) and its relation with urban development, Natural Hazards, Volume 59, Issue 3, pp. 1753-1771 (2011)

9. Koudogbo, F. N., Duro, J., Arnaud, A., Bally, P., Abidin, H. Z., and Andreas, H., Combined X- and L-band PSI analyses for assessment of land subsidence in Jakarta, Proc. SPIE, Remote Sensing for Agriculture, Ecosystems, and Hydrology XIV, 8531, 853107, doi:10.1117/12.974821, 2012 (2012)
10. Ng, A.H.-M., L. Ge, X. Li, H.Z. Abidin, H. Andreas, K. Zhang, Mapping land subsidence in Jakarta, Indonesia using persistent scatterer interferometry (PSI) technique with ALOS PALSAR. Int. J. Appl. Earth Observ. Geoinf. 18, 232-242 (2012)

11. Chaussard Estelle, Amelung F, Abidin HZ, SanHoon Hong, Sinking cities in Indonesia: ALOS PALSAR detects rapid subsidence due to groundwater and gas extraction. Remote Sensing of $\begin{array}{lllll}\text { Environment } & 128 & \text { (2013) } & 150 & -161\end{array}$ http://dx.doi.org/10.1016/j.rse.2012.10.015

12. Marfai, M.A., Almohamad, H., Dey, S., Susanto, B and King, L., Coastal dynamic and shoreline mapping: multi-sources spatial data analysis in Semarang Indonesia. Environmental Monitoring and Assessment, 142, pp. 297-308 (2008)

13. Murdohardono, D., Sudradjat, G.M., Wirakusumah, A.D., Kuhn, F and Mulyasari, F., Land Subsidence Analysis through Remote Sensing and Implementation on Municipality Level; Case Study: Semarang Municipality, Central Java Province, Indonesia. Paper presented at the BGR-GAI-CCOP Workshop on Management of Georisks, 23-25 June, Yogyakarta (2009)

14. Kuehn, F., Albiol, D., Cooksley, G., Duro, J., Granda, J., Haas, S., Hoffmann-Rothe, A and Murdohardono, D., Detection of land subsidence in Semarang, Indonesia, using stable point's network (SPN) technique. Environmental Earth Sciences, DOI 10.1007/s12665-009-0227-x (2009)

15. Lubis, A.M., Sato, T., Tomiyama, N., Isezaki, N and Yamanokuchi, T., Ground subsidence in SemarangIndonesia investigated by ALOS-PALSAR satellite SAR interferometry, Journal of Asian Earth Sciences, 40, 5, 30 March, pp. 1079-1088 (2011)

16. Andreas, H., Abidin, H.Z., I.Gumilar and Teguh, P.S.,Recent land subsidence in Semarang (Indonesia) as estimated using GPS Surveys. ISGNSS 2016 Conference Proceeding. Taiwan (2016)

17. Sutanta, H., Rachman. A., Sumaryo and Diyono, Predicting Land Use Affected by Land Subsidence in Semarang Based on Topographic Map of Scale 1:5.000 and Leveling Data. (Proceedings of the Map Asia 2005 Conference (in CDRom), Jakarta, 22-25 August 2005)

18. Mazzotti, S., Lambert, A., Van der Kooij, M., \&Mainville, A., Impact of anthropogenic subsidence on relative sea-level rise in the Fraser River delta. Geology, 37(9), 771-774 (2009) http://dx.doi.org/10.1130/G25640A.1

19. Andreas, H., Abidin, H.Z., Gumilar, I., Sidiq, T.P., Yuwono, B, Adaptation and mitigation of land subsidence in Semarang, AIP Conference Proceeding 1857, 4987088 (2017)

20. Andreas, H., Zainal Abidin, H., Pradipta, D., Anggreni Sarsito, D., Gumilar, I, Insight look the subsidence impact to infrastructures in Jakarta and 
Semarang area; Key for adaptation and mitigation. MATEC Web of Conference 147, 08001 (2018)

21. Hudnut K.W.,Earthquake Geodesy and Hazard Monitoring. U.S. National Report to IUGG 19911994. Rev.Geophys, vol 33 Suppl.,@ 1995 American Geophysical Union (1994)

22. Bock Y, Prawirodirdjo L, Genrich JF, Stevens CW, McCaffrey R, Subarya C, Puntodewo SSO, and Calais E, Crustal motion in Indonesia from global positioning system measurements. J Geophys Res 108(2367). doi:10.1029/2001JB000324 (2003)

23. Okada, Y., Surface deformation due to shear and tensile fault, Bulletin of Seismological Society of America (1985)

24. Hanifa, N. R., Sagiya, T., Kimata, F., Efendi, J., Abidin, H. Z. and Meilano, I., Interplate Coupling Model Off The Southwestern Coast of Java, Indonesia, Based on Continuous GPS Data in 20082010. Earth and Planetary Science Letters (2014)

25. Hayes, G. P., Wald, D. J., \& Johnson, R. L., Slab1.0: A three-dimensional model of global subduction zone geometries,Journal of Geophysical Research: Solid Earth (2012)

26. Holzer and Thomas L., Land subsidence caused by groundwater withdrawal in Urban areas, GeoJournal 11.3 245-255. (Reidel Publishing Company 1985)

27. Abidin, H.Z., H. Andreas, M. Gamal, I. Gumilar, M. Napitupulu, Y. Fukuda, T. Deguchi, Y. Maruyama, E. Riawan, Land subsidence characteristics of the Jakarta Basin (Indonesia) and its relation with groundwater extraction and sea level rise, in Groundwater Response to Changing Climate, IAH Selected Papers on Hydrogeology No. 16, ed. by M. Taniguchi, I.P. Holman, chap. 10 (CRC Press, London, 2010a), pp. 113-130, ISBN: 978-0-41554493-1 (2010a)

28. JICA, Lesson learn from land subsidence in Tokyo Japan. Presentation on "high Level Meeting on Subsidence". Balai Kota DKI Jakarta Indonesia 2014 (2014) 